\title{
Haruki Murakami's Deconstructive Reading of the Myth of Johnnie Walker and Colonel Sanders in Kafka on the Shore
}

\author{
Djakaria, J. D. and Limanta, L. S. ${ }^{1}$ \\ ${ }^{1}$ English Department, Petra Christian University, Surabaya, INDONESIA \\ e-mail: luc_jovita@hotmail.com, satya@peter.petra.ac.id
}

\begin{abstract}
This study aims to analyze how Haruki Murakami reads the real icons of Johnnie Walker and Colonel Sanders in Kafka on the Shore deconstructively. First, we will focus on the signification process of the icon, which are to a great extent molded by advertisements, and then on the deconstruction of their signifieds. For the purpose, we will apply Barthes' idea of myth. We are also interested in revealing how Murakami constructs Johnnie Walker and Colonel Sanders to be characters in the novel. The analysis shows that the construction of the icons through advertisements leads to the creation of their mtyhs, and then Murakami reads them deconstructively to be opposite signifieds.
\end{abstract}

Key words: Signifier, signified, myth, deconstruction, intertextuality, icons.

\section{INTRODUCTION}

In the past, literary works challeged the writer to create something 'iconic', as answered by Mary Shelley with her Frankenstein, Bram Stoker's Dracula, Don Vito Corleone of Mario Puzo's The Godfather, and many more. In contemporary works, the mentioning of icons is not something to be afraid of. One of the famous contemporary writers, internationally popular for his work Norwegian Wood, is Haruki Murakami who uses icons outside literary works to be his characters. Murakami is the author of the 2006 Franz Kafka award and New York Bestselling Kafka on the Shore, a neat composition of the world of Kafka Tamura, a 15-year old runaway who is to be the toughest boy in the world. He undergoes a journey against the oedipal prophecy written by himself and search for his mother and sister, two figures lost in his childhood. During the magical travel, Kafka also met two world-renowned icons, now talking and living: Johnnie Walker and Colonel Sanders.

Murakami borrows two very famous worldwide icons as the characters in Kafka on the Shore, that is 'Johnnie Walker' and 'Colonel Sanders.' Johnnie Walker is a scotch whiskey icon that is present as the trademark of the brand Johnnie Walker itself. A symbol portraying a man with a white hat, suits, and sticks, Johnnie Walker presents the striding man of Scotland ("History of Johnnie Walker"). Murakami also brings Colonel Sanders, the icon of international franchise of Kentucky Fried Chicken. A man in white suit, usually portrayed holding a bucket of his invented recipe of fried chicken, Colonel Sanders is a figure whom people easily remember. It is also important to note that both icons are associated with something greater in ideological sense than just the product they represent, as Eiffel tower is a symbol of French nationalism. This association, which occurs in layered processes, is called 'myth', a term coined by Roland Barthes to describe a conceptual idea of a system evolving around a sign (Stoica, 2011, para. 6). Mythology, by definition, is a study of type of speech aimed to examine the connotation operating inside a text. In a myth, there are two semiological systems operating; one is the language-object relation forming a "language which myth gets hold in order to build its own system," and the other one is myth, called as metalanguage, the second language "in which one speaks about the first" (Barthes, 1972, p. 112).

Portraying Johnnie Walker and Colonel Sanders and placing them to a journey which gives them a new meaning for their existence itself are eventually an attempt to deconstruct the myth of the two icons in the novel. As icons, both of them have possessed features in which the icons are made for some certain purposes, as one marketing material explains to be a "brand recognizable anywhere in the world that has survived economic convulsions" (Vedolin, 2010, para. 2). Murakami gives new traits to the icons as 
characters, which are the total opposite from the positive meanings. Johnnie Walker is, in Murakami's deconstructive reading, a mad man and cat-killer, while Colonel Sanders appears to be a rich man who is very generous, humorous, and yet a pimp who distributes 'chicks' (an informal term for girls, usually refering to prostitutes). Thus, there is a deconstruction of the essence of the icons, from being mythically created for positive image in reality to being a negative one in the novel.

We are especially interested in how Johnnie Walker and Colonel Sanders who are chosen in the novel to become characters in the novel, but also the process of deconstructing the icons and the myth surrounding the icons. Barker (2004) mentioned that "to deconstruct is to take apart, to undo, in order to seek out and display the assumptions of a text" (p. 70). Hence, the definition of deconstruction is a process of dismantling a text and scrutinizing the system operating in it. Therefore, we will focus specifically on analyzing the two icons and their construction and decostruction of their signifieds in the novel.

Vincent B. Leitch (1983) noted that "[t]he text is not an autonomous or unified object but a set of relations with other texts. [...] Every text is intertext" (p. 59), meaning that one text cannot be isolated from its relation to other texts outside the text itself. Thus, reading the characters deconstructively might not be possible if they are read outside their context.

Applying this theory, we will analyze Johnnie Walker and Colonel Sanders, the icons and characters in Murakami's novel, by first identifying the construction of the two icons and the myths surrounding them. By this, we will apply intertextuality, analyzing the icons from advertisements and in the novel. Lastly, we will use deconstruction to find the binary operations from these two texts and how Murakami reconstructs the icons to be the characters as well as their signifieds being reversed in the novel.

\section{CONSTRUCTION AND DECONSTRUCTION OF JOHNNIE WALKER MYTH}

Johnny Walker, the signifier we are discussing here, is both an icon and a brand name of world-renowned Scotch whiskey. At first, the icon was modeled after the founder of the brand, John Walker. He was depicted as a middle-upper class man of the society instead of man from working class. As intended to attract upper class society, the icon was designed with distinctive features and merry appearance:

His top hat, walking stick, breeches and riding boots promise a refined product for an upscale market. Combine that with his elusiveness [...] and it makes for a very attractive symbol for the rung-climbing careerist set with money to spend (Vedolin, 2010, para. 3).

The icon, a faceless striding man with the same long coat, tall hat and boots, and walking stick to the right direction, gives people a sense of sophisticated icon of a whisky by the appearance of a high-end man with an edgy tagline "keep walking", which notates progress and development to something positive.

As we see the icon of Johnnie Walker, we would then see the very product it symbolizes: the Scotch whiskey. Johnnie Walker appears as a logo sticking on the bottle of Red Label and on the boxes of all the whiskey varieties. The icon of striding man is thus associated with the liquor produced from malts, enunciating liquor presented by a gentleman with high hat and who 'keeps walking.' Johnnie Walker is a sign of drinking a special whiskey, which is the favored scotch.

Imbued with these traits of icon is the second level of signification, in which Johnnie Walker is more than a mere sign of striding man with a context of advertisements. Many advertisements are based on the Johnnie Walker icon, which then reinforces new signification from being an icon of sophisticated man into a more 'living' one, a new essence. It is from advertisements that society defines Johnnie Walker, and the campaigns involving Johnnie are intended to incept the ideas on the whiskey-branding image. The decoding of meaning is possible because of the "shared meaning systems and cultural codes" (as cited in Stoica, 2011, para. 3).

Everyone in the advertisements takes the striding man's good product and uses it both to convey good choice, nonetheless signifying the whisky as one's good choice, too. Stoica (2011) argued that:

... the entire brand has been given the meaning of 'success.' ... So, associating the Johnnie Walker brand with an individual may result in reification (Goldman 1987: 718), through which individuals are thought of in terms of the brands they use and the social meaning of those brands (para. 3).

The intended essence of Johnnie Walker through the meaning reinforcement from the advertisements is a mere signification process of the third level. The icon incepts an idea that he 'walks' around the world, gathers and inspires successful people he met, as well as the idea how a successful man should look like and do. Hence, Johnnie Walker is a personalization of success itself. 
All traits in Johnnie Walker are intended to signify success as expressed by progress ("BBH's campaign," 2008, para. 5), but there is something more than just a mere success. Success is something idealized, something people want to see and at the same time identify themselves to be the men in advertisements. Stoica (2011) noted that "Keep Walking depicts 'idealised images' - created through social norms that have evolved over time" (para. 10). However, 'success' is not only something that is universal. The advertisements use men with appropriate appearance, interest, skill, and behavior to portray a typical success. From this point, Johnnie Walker becomes a new signifier of civilized and elite people.

Beginning from the suit, which mirrors how a gentleman should wear, the icon continuously points out how to be a successful man in life by becoming 'civilized.' Moreover, success is seen as an idealized image where everyone can be successful, but at the same time, there are only special traits to be possessed to be successful, as in dressing elegantly. Thus, in Johnnie Walker, there exist two myths on consuming the whiskey: that drinking whiskey might give success, and that drinking whiskey might make one 'civilized' as well.

We have discussed how Johnnie Walker icon undergoes two semiological systems through signification process. Herein, we would like to show the deconstruction process on the novel through the binary operations done by Murakami. As a borrowed icon for the character, Johnnie Walker is physically depicted as:

[...] tall, thin, and wearing a black silk hat. $[\ldots] \mathrm{He}$ had on a form-fitting red coat with long tails, a black vest, and long black boots. His trousers were as white as snow and fit him perfectly. One hand was raised to the brim of his hat, like he was tipping it politely to a lady. His left hand gripped a black walking stick by the round, gold knob (Murakami, 2002, p. 68).

Murakami gives Johnnie Walker a 'human' form since it is described that Johnnie has a face.

The signifier on the very first level of language-object relation is then associated with the icon's original signified, that is the product whiskey itself. The Scotch whiskey is not altered, but yet the relationship between Johnnie and the liquor changes; Johnnie is depicted as consuming the whiskey.

The man sat back down and crossed his legs. He picked up a glass on the desk and took a sip of whisky. Ice cubes clinked in the glass. "I hope you don't mind if I indulge?" (p. 68).

...

He lifted his glass of whisky and took a drink. (p. 73)

Therein, Johnnie Walker is not only associated to the whiskey. By consuming the whiskey, Johnnie is thus inferred that he is also a consumer and is able to be
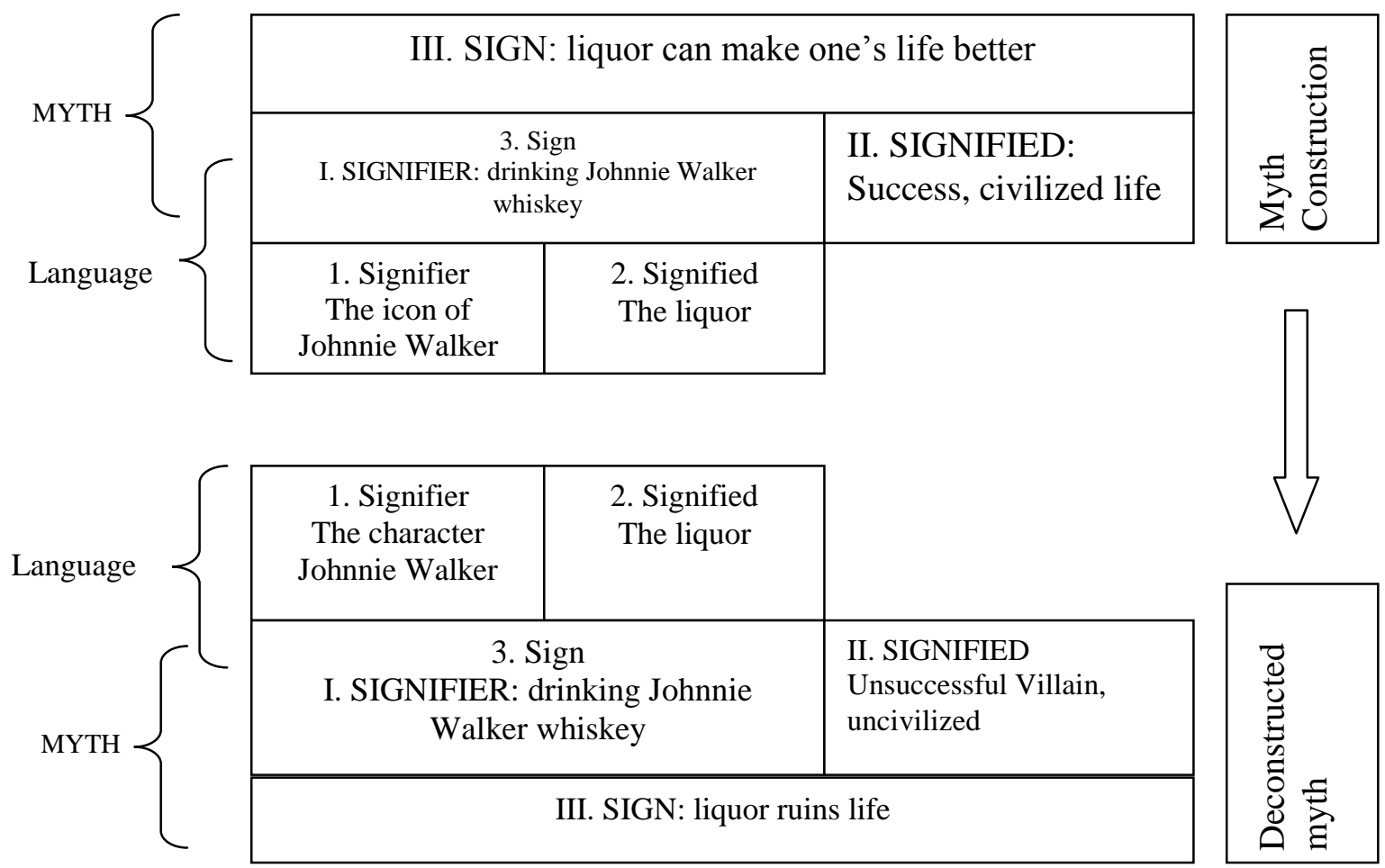

Figure 1. The Process of Johnnie Walker's Myth Construction and Deconstruction 
successful and civilized as in the previous myth that liquor might make someone's life better. However, it is through this myth now that Murakami deconstructs the icon to be Johnnie Walker who kills cats. The myth is modified by changing the previous signified of drinking whiskey.

In the previous myth and its signified, presenting Johnnie Walker's whiskey that makes one successful, Johnnie Walker is thus posited as the 'hero' of all men. The icon is called 'hero' because through him, the consumer will get the desired 'success', which is done through drinking the whiskey of Johnnie Walker. It means that Johnnie Walker is a 'vehicle' for success and also a helper for getting success itself, as how the advertisement depicts 'successful' men who conquer their fears and move forward. In this advertisement, Johnnie is a positive figure, a hero who can also help people to be as successful as himself. A typical hero might get happiness, as what the advertisements aim:

The main emotion targeted within the Keep Walking campaign may be happiness, because there is a strong emphasis in the different adverts on individuals achieving happiness through personal, non-material success (Stoica, 2011, para. 5).

It can be inferred in the quotation above that Johnnie Walker is typically drawn as a successful man who would get satisfaction and happiness from nonmaterial success. Johnnie Walker and those who drink whiskey might be inspired to be a hero to do something useful for the society, and eventually receive happiness by then.

In the novel, however, Murakami deconstructs Johnnie Walker and shifts the pivoting center into 'Johnnie Walker is a villain in its relation to 'failure.' As success will lead to happiness, the deconstructed concept is transformed into 'a failure who will face dooms' throughout the Johnnie Walker character, which is indicated by making him into a negative figurine, a cat-killer:

I'm the one who cut off all those cats' heads," he said. He lifted his glass of whisky and took a drink. "Im collecting them."

"So you're the one who's been catching cats in that vacant lot and killing them."

"That's right. The infamous cat-killer Johnnie Walker, at your service." (Murakami, 2002, pp. 75-76)

...

It takes a lot of time and effort to gather and kill this many cats. I'm killing them to collect their souls, which I use to create a special kind offlute.
Perhaps in the end I'll be able to make a flute so large it'll rival the universe." (p. 76)

Transforming Johnnie Walker into a figure who states that he takes lives consciously, although not killing human, is one oppositional reading of the image of a 'hero' asserted by the signified of success in the icon. This depiction of villain is then crystal clear; people see a 'killer' who has specific intention to fulfill his own desire as having bleak future, or no future at all.

Hence, the new signified Murakami gives to the myth via the binary play of real icon and character is a message of 'if you do not drink the whiskey, you might not always fail to be a hero.' In the novel, the message is 'if you drink the whiskey, you might just be the faltered ones like Johnnie Walker.' Arons (2010) stated that the ads "emphasized every man's determination to follow his dreams and pursue his agendas" (p. 3), which is pictured by Murakami as a man who is determined to do everything for his ambition, too, but for a bad purpose. Murakami thus ended the life of Johnnie Walker miserably, to emphasize the wrath of Johnnie Walker and the ending he deserves as a villain:

He didn't cry out, either. Instead, he laughed out loud. His hat fell to the ground, and his eyeball was soon shredded and hanging from its socket.[...] He looked like he couldn't breathe, either, but still he held his sides and shook with soundless (Murakami, 2002, p. 239)

On the quotation above, Johnnie Walker as a villain meets his ending miserably as a person who consumes liquor and becomes mad, seen in the phrases 'still the man kept on laughing', and 'shook with soundless laughter.'

The second signified we will discuss is how drinking whiskey might indulge the drinker in being more 'civilized.' For that purpose, we would explain the binary play within Murakami's deconstruction of the icon, and what he makes the character to be.

Being civilized implies that the quality to possess and access whiskey is identified by the choice of look, which identifies one's earning. One of the characters Johnnie Walker meets in the novel gushes that he "doesn't drink or smoke. [Because he is] poor enough to get a sub City, [he] can't afford that" (p. 68). Herein, it is clear that to be able to consume whiskey, one must have the money. Thus, drinking whiskey as a part of 'being civilized', for Murakami imposes that whiskey cannot make one successful; it is the consumers who should be 'civilized' first before being able to consume the liquor, not that the liquor make one civilized. 
The core value that is also displayed throughout the advertisements is thus deconstructed vis-à-vis with the personality and behavior of Johnnie Walker as a character in the novel. Johnnie Walker is depicted as a person who stands out because he is a 'freak.'

Still whistling his jolly tune, Johnnie Walker sawed the cat's head off. The teeth of the saw crunched through the bone and severed it. [...] Johnnie Walker lovingly placed the severed head on the metal tray. [...] He stopped whistling for a second, extracted something stuck between his teeth with a fingernail, popped it in his mouth and carefully tasted it, then smacked his lips, satisfied, and gulped it down. $[\ldots]$ The satisfied smile. Wiping the blood away with the back of his hand. All with "Heigh-Ho" as background music (p. 79).

It is seen that Johnnie Walker is thus not a positive power of making one civilized anymore. Looking at the words 'jolly' and 'satisfied,' Johnnie is a cat-killer who is abnormal, as he is described as joyfully killing the cats. He no longer belongs to 'normal' and civilized society. In contrast, Johnnie Walker shows the side of being uncivilized, which is beyond any justification, such as in killing and torturing.

Moreover, he also enjoys the killing and does it after drinking the whiskey, which he does before the torture and murder.

The man sat back down and crossed his legs. He picked up a glass on the desk and took a sip of whisky. Ice cubes clinked in the glass. "I hope you don't mind if I indulge?" (p. 68)

The quotation above shows the moment before killing. It is clear that he drinks whiskey first before committing his act. This is also a binary play of 'drinking whiskey is good and makes you civilized.' At the opposite pole it signifies that if one does not drink, it does not mean that $\mathrm{s} / \mathrm{he}$ is uncivilized. In other words, Johnnie Walker is 'lunatic' because of drinking. The effect, he enjoys torturing. Johnnie is not a respected gentleman because of alcohol. He even contradicts his enjoyment on savoring the stillbeating heart of the cats with his own statement before, indicating the liquor effect on him:

Listen--I'm not killing cats just for the fun of it. I'm not so disturbed I find it amusing," he went on (p. 76).

...

It all happened in an instant. The belly split wide open and reddish guts spilled out. [...] Still to the accompaniment of "Heigh-Ho," he thrust his hand inside the cat's body and with a small scalpel skillfully cut loose the tiny heart. [...]
Then, as if it were the most natural thing in the world, he popped the heart into his mouth and began chewing silently, leisurely savoring the taste. His eyes glistened like a child enjoying a pastry hot from the oven. ... "Fresh and warm. And still beating in my mouth" (p. 78).

Also previously stated that the cat is only paralyzed but able to feel pain, the cat-killer Johnnie Walker is truly a mad man. The sentence "I'm not killing cats just for the fun of it" and "I find it amusing" are just contradictory. When he says "I'm not so disturbed," it is quite true since it is his mind being disturbed by the alcohol. His logic is disturbed. Johnnie Walker is thus a mere lunatic who does crazy things because of the liquor effect. It is a binary play from the advertisement, which implies that drinking whiskey must be good and makes one civilized.

Hence, the construction and deconstruction of Johnnie Walker undergo two levels of signification process. On the construction of the myth, Johnnie Walker implies that by drinking the whiskey one becomes civilized. On the deconstruction of the myth, drinking whiskey is not making one civilized; instead, one becomes a lunatic man because of the liquor effect and unable to control himself. Thus, Murakami's deconstructive reading turns Johnnie Walker's whiskey myth upside down.

\section{CONSTRUCTION AND DECONSTRUCTION OF COLONEL SANDERS MYTH}

Colonel Sanders is a famous icon of worldwide popular franchise Kentucky Fried Chicken. Taking the image of the restaurant founder Colonel Harland David Sanders, he himself being an iconic American entrepreneur, his legacy on changing the world with fast food is what makes him an important icon that "anyone who grew up in America in the second half of the 20th century" would recognize instantly (Ozersky, 2010, para. 4). In the following section, we would analyze the icon and find the myth surrounding the icon by historical-biographical approach, as well as several advertisements as tools to understand the signifieds of the icon.

Firstly, Colonel Sanders' appearance as a signifier consists of a plain white suit and trousers with a black string tie knotted tidily. Furthermore, Colonel Sanders appeared to be old, with snow white hair and white goatee beard, as well as glasses. This description of the icon signifies Colonel Sanders as a good man who sells a good product. Wright (2010) explains that the color white infers " $\mathrm{h}] \mathrm{ygiene}$, sterility, clarity, purity, cleanness, simplicity, sophistication, efficiency" (para. 
3 ), indicating that the usage of white signifies a cleanness of the product itself, in tune with the fact that Colonel Sanders is an icon for food, which requires hygiene and cleanness for consumption. Moreover, the elderly figure of Colonel Sanders, as indicated by the grey hair and goatee indicates an experienced figure. Grey hair, a trait of elder people, reflects qualities of being 'old', that are wise, experienced, and trusted. The iconic smile of Colonel Sanders might also indicate the friendliness and service that one might get from Colonel Sanders and the product. Colonel Sanders is a good man who sells a good product, as well as marketable and financially stable man.

It is then the signified of Colonel Sanders' icon that people have in mind. The appearance of the iconic Colonel Sanders is a mere signifier to what he sells, that is fried chicken. Colonel Sanders is turned to be a figure associated most with the fried chicken he sells. Ozersky (2010) explains that:

Sanders was the living embodiment of what his food supposedly stood for. His white suit wasn't the invention of a marketing committee; he wore it every day and was never seen in public for the last 20 years of his life in anything else (para. 4).

The character and figure of Colonel Sanders are thus inseparable from the commodity itself. The iconic man has given meaning of fried chicken as commodity throughout advertisements.

We would begin scrutinizing the signified of this sign by first doing a biographical approach on Colonel Sanders. Colonel Sanders invented his recipes and conducted the restaurant from his own kitchen. Furthermore, he was also dedicated to stand in front of his restaurant and called passing cars as means of promotion (Topmiller, 2010, para. 3). Such acts for his business were continued until his death in 1980 .

Colonel Sanders himself appears as a real figure of the Kentucky Fried Chicken head in promoting the fried chicken. There are two types of advertisements. The old ones involve the still-alive Colonel Sanders himself marketing his product, the others feature product, fried chicken commodity. In most advertisements, there are portrayals of how families enjoy his product with smiling faces. On the advertisements that do not portray Colonel Sanders, the ads mostly show the crispness of brown-fried chicken, indicating the tastiness of the commodity for the prospective consumers.

Relating to this, we would like to first elaborate on capitalism, as explained by Barker (2004): ...[it is] grasped as a mode of production premised on the private ownership of the means of production. [...] While the legal framework and common sense thinking of capitalist societies may declare that workers are free agents and the sale of labour a free and fair contract, this obscures the fundamental process of exploitation at work. This is so because capitalism aims to make a profit and does so by extracting surplus value from workers. The realization of surplus value in monetary form is achieved by the selling of goods (which have both 'use-value' and 'exchange-value') as commodities. (p. 29)

Capitalism is thus a mode of production wherein the labors do not receive as many as "those who work less in the hierarchy" (Wolff, 2011, para. 5). Based on the advertisements, it is shown that the Colonel is the direct controller of everything in the process of spicing the chickens and frying them (the workers do them all). Moreover, it is the KFC president who takes the merit on getting the surplus value from the workers and claims the chicken as his product. Nonetheless, Colonel Sanders here is seen as the one who gives the 'service' from his very own hand, a trait of capitalism wherein he receives the recognition from public and becomes the symbol of quality cooking while the food-processing is done by the workers.

Defined as a "mode of production premised on the private ownership of the means of production", capitalism turns "the value of the labor taken to produce goods, which become the property of the bourgeoisie, [to be] more than the worker receives for it" (Barker, 2004, p. 20). However, the aim is "directed towards making the greatest possible profits for successful organizations and people" ("Capitalism"), meaning the purpose of capitalism is still to bring profit for the sake of human being. In Kentucky Friend Chicken franchise, Colonel Sanders as the private owner of the world-renowned business serves the commodity, that is chicken, not only for the sake of profit but also for the labors as well as to serve human beings with the commodity. It does not matter how many labors are required to mass-produce the chicken, because eventually this system helps "continual revolutionizing of the means of production and the forging of new markets" (Barker, 2004, p. 20). Therefore, chicken as commodity is served as the object of capitalism itself; the center is still human being, for every means of production involves human being and the result is aimed to make human live better. 
Taking on this new signified of capitalism, we discover the myth circulating around the icon. As eating Kentucky Fried Chicken is a confirmation that consuming the food that Colonel Sanders makes would always be good, the myth now turns to be that Colonel Sanders provides the best chicken through the best service, proven by his elderly, experienced look as well as his perseverance, and will ensure the service to be good for the sake of others. Throughout the usage of labor and capitalist mechanism of product creation, in addition to the portrayal of Colonel Sanders in the icons as a hard-working and talented chef who mass-produces his chickens for the sake of the consumers, Colonel Sanders gives jobs to thousands of people in "more than 600 franchised outlets for his chicken in the United States and Canada" (Topmiller, 2010, para. 5).

We have discussed the construction of Colonel Sanders as an icon and how it constructs a new myth, namely capitalism provides the best service and product for the welfare of human beings. In the novel, Murakami deconstructs capitalism to be at its worst: he treats human being not as a subject to be satisfied by Sanders' product. Instead, human being is now the object or commodity, and fried chicken or 'chicks' are just his tool. In addition, Murakami deconstructs Colonel Sanders to be a pimp, an agent for call girls throughout the novel. Thus, we would like to discuss how the deconstruction and binary opposition occur in this text, scrutinizing from the depiction of Colonel Sanders as a pimp and the deconstruction of capitalism as a new signified given by Murakami.

From the beginning, Colonel Sanders is described exactly like the old Kentucky Fried Chicken icon, with "a white suit, [w]hite hair, a serious pair of glasses, a white mustache and goatee, white shirt, and string tie." (Murakami, 2002, p. 142), indicating his identity:

"I don't just look like Colonel Sanders. It's who I am."

"The fried-chicken guy?"

The old man nodded heavily. "One and the same." (p. 142)

[He is really] that of a famous capitalist icon. (p. 145)

It is clear that Colonel Sanders in the novel is identified exactly as the KFC's Colonel Sanders. The character is not only similar, but he is the icon itself. On the contrary, Murakami depicts the Colonel's pose who "held both hands out in front of him like he was carrying a tray" (p. 142) on calling the customers to be a pimp-like pattern of works, as shown by the interaction of Colonel Sanders with a character named Hoshino. Hoshino questioned him:

But if you're the real Colonel Sanders, what the heck are you doing working as a pimp in a back alley in Takamatsu? You're famous, and must be raking in the dough from license fees alone. ( $\mathrm{p}$. 142)

This is contradictory to the image of real person based Colonel Sanders icon, as now the center moves from being an elderly figure who gives good service to people to be a figure who pimps, gives 'good' service with such a peculiar suit. Pimping is an action generally blamed by society as deviant and immoral, thus moving Colonel Sanders' traits from positive into negative image.

How about a nice girl?"

[...] My girls do it all--hand job, BJ, whatever you want, including the old in-and-out." (p. 143)

From this point, it is clear that the center of this text is contradictory to the real icon's center. While both Colonel Sanders, the icon and character, center on what they do, the main difference of his 'service' is the position of subject and object in the capitalism.

This system is what is deconstructed by Murakami. In the novel, human being no longer becomes the subject for Colonel Sanders, as now the human being is the object of Colonel Sanders' business. Therein, the commodity becomes the subject, for now the commodities are prostitutes. We would now explain the shifts of human being from the subject to the object. First of all, human being is decentered through the diminishing of the importance of a woman through description of her as a "veritable sex machine" who is "[...] our top girl. Luscious breasts, skin like silk. A nice, curvy waist, hot and wet right where you like it, a regular sex machine" (p. 149). It was clear that herein Colonel Sanders treats human as an object, a commodity he sells. Thus, the importance of human being, namely the absence of the prostitute's name signifies the diminished importance of human as a subject; human is now an object for sexual satisfaction.

Moreover, the decentered human is overshadowed by the importance of the service itself, not the specific traits of girls: "My girls do it all--hand job, BJ, whatever you want, including the old in-and-out." (p. 143). Here, the girl is not important, but what she does (namely the service) is. It is thus clear that the importance of Colonel Sanders' works are not about the service to satisfy human being anymore, as done by many other capitalistic business. The center of importance is now the service being provided by 

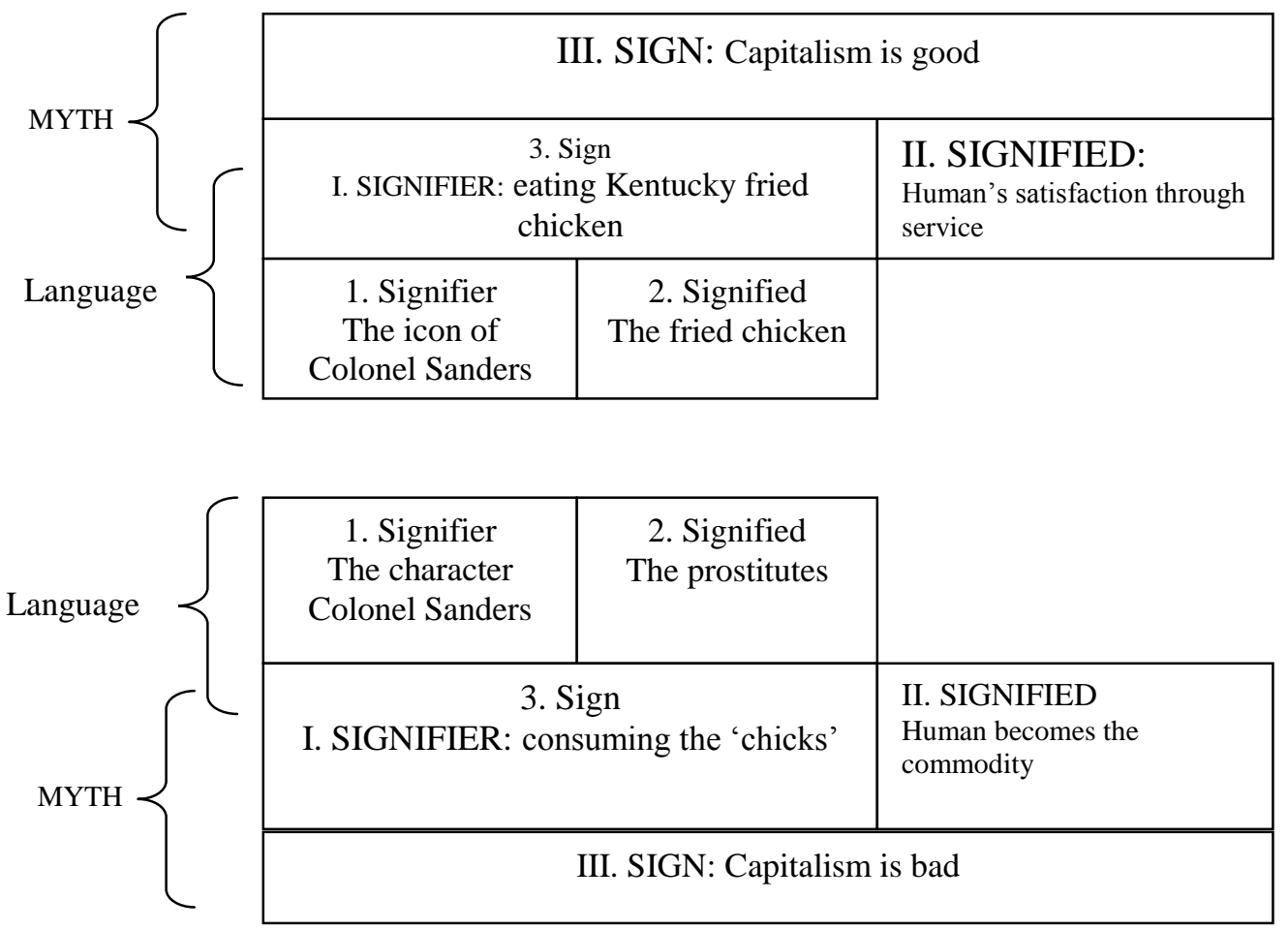
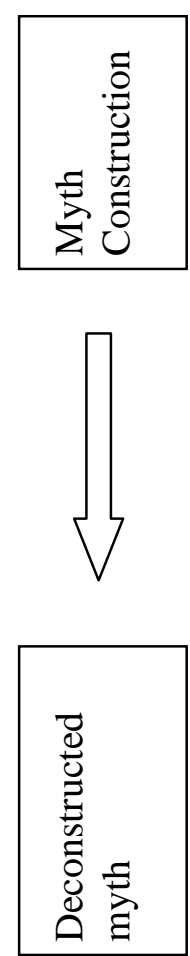

Figure 2. The Process of Colonel Sanders' Myth Deconstruction

Colonel Sanders and the 'chicks' (an informal term for girl), that is the commodity. Hence, the service becomes the center whilst now human being is peripheral. What matters is the service, no matter who the customer is or who the girl is, neglecting the importance of individuality.

The self and object relationship is a part of the capitalism deconstruction. The signified has previously been stated as 'if you eat KFC, you will be provided with one-of-a-kind fried chicken that has been proven delicious', meaning that one can consume such a great food. However, the center now moves to the 'human being as a commodity' as a trait of capitalist 'profit-driven business mechanism' to achieve success, changing the signified into consuming Colonel Sanders' 'chicks' (Barker, 2004, p. 20). Before, service was only one tool to satisfy human; now, service is the one dominating the human as objects. Human being becomes commodity in the novel, and thus it becomes the peripheral whilst the commodity itself becomes the center.

All in all, Colonel Sanders' shift from chicken grandeur to pimp signifies the opposite purpose of capitalism, which is human being. The deconstructed signified is that human being as a subject for the commodity becomes the commodity itself, which then puts human being into an object throughout Colonel Sanders representation. Capitalism herein is inferred as bad, as a power which controls human instead of human taking control of it.

To summarize the analysis, we found out that the icons as characters are the new signifieds of Murakami's reading of their myths. As such, Johnnie Walker is turned to be a mad man, deconstructing the myth that drinking whiskey turns one to be a more refined being. Furthermore, Colonel Sanders as a pimp reflects the diminishing of human as a subject to be an object, turning the signified of providing the best service to human being into making human being as a commodity, therefore stating that capitalism is a bad thing.

\section{CONCLUSION}

To conclude, the analysis has proven that there is a deconstruction of the icon signified in the novel, and there are serious issues being discussed by the author throughout the progressing story. Johnnie Walker is an icon that intends to mirror the power of civilized society and that Johnnie is a good gentleman that will enact success and stability. The signified of Johnnie Walker that 'drinking whiskey might make one successful' and 'drinking whiskey might make you civilized' thus leads to the intended myth that drinking liquor can improve one's life. Meanwhile, Colonel Sanders is a man that might ensure you a good product and it will satisfy the consumers 
because it is Colonel Sander's, not others.' Colonel Sanders thus signifies a myth that capitalism is good.

The signified of the icons are deconstructed by Murakami to be the characters in the novel. Drinking Johnnie Walker whiskey as a myth of success and being civilized is deconstructed by making Johnnie Walker a 'villain' instead of hero (in relation to the success it brings). The binary comes to play, as Johnnie Walker-character becomes the uncivilized one by the effect of the whiskey, that is 'becoming mad.' Thus, Johnnie Walker is the real opposite of the positively constructed icon, thus deconstructing the myth to be that liquor ruins life. Colonel Sanders icon is deconstructed to be negative as well. Deconstructed to be pimp in the novel, Murakami shows the binary play of the subject and object. For Murakami, the object is not the chicken anymore, but the human that consumes the 'chicken,' the call-girls that Colonel Sanders sells in the novel. Thus, the importance of human is diminished and human is a mere object, the subject being the commodity itself. The myth is deconstructed to be that capitalism is bad.

A character borrowed from a real icon might provide a unique effect as it implies a new meaning, as well as how the author comes to play with the binary opposition. As a reading attempt to read the two iconic characters, it is clear that the deconstructed myths are simply revealing the other side of the icons, by reversing the signified of the two icons. Thus, it also proves that both Johnnie Walker and Colonel Sanders in Murakami's novel are examples of reading myth and its deconstruction.

\section{REFERENCES}

Arons, M. de S. \& Driest, F. van den. (2010). The global brand ceo-Building the ultimate marketing machine. New York: Airstream.
Barker, C. (2004). The sage dictionary of cultural studies. London and Thousand Oaks, CA: Sage.

Barthes, R. (1972). Mythologies. New York: Hill and Wang.

BBH's campaign for Johnnie Walker awarded Grand Prix at IPA Effectiveness Awards. (2008). Retrieved from http://www.ipa.co.uk/News/ BBHs-campaign-for-Johnnie-Walker-awardedGrand-Prix-at-IPA-Effectiveness-Awards.

Capitalism. (2013). In Cambridge Dictionaries Online. Retrieved from http://dictionary.cambridge.org/ dictionary/british/capitalism?q=capitalism.

History of Johnnie Walker. (n.d.). Retrieved from http://www.johnniewalker.com/ en-us/history.

Leitch, V. B. (1983). Deconstructive criticism: An advanced introduction. New York: Columbia University Press.

Murakami, H. (2002). Kafka on the shore. New York: Vintage.

Ozersky, J. (2010). Taste of America: Kfc's Colonel Sanders: he was real, not just an icon. The Time. Retrieved from http://www.time.com/time/nation/ article/0,8599,2019218,00.html.

Stoica, R. (2011). Bottled success-a cultural and semiotic analysis. Retrieved from http://wishperingchicken.files.wordpress.com/2011/02.

Topmiller, S. (2010). Colonel sanders personal assistant helps keep original celebrity chef's memory alive. Retrieved from http://smnr.Akamediainc.Com/kfc-colonel-sanders/

Vedolin, O. (2010). Johnnie Walker. Retrieved from http://sites.google.com/site/olivervedolin/johnnie - walker.

Wolff, J. (2011). Karl Marx. In Edward N. Zalta (Ed.), The stanford encyclopedia of philosophy (Summer 2011 Edition). Retrieved from http://plato. stanford. edu/archives/sum2011/entries/marx.

Wright, A. (2010). Psychological properties of colours. Retrieved from http://www.colour-affects. co.uk/psychological-properties-of-colours. 